\title{
Optic Disc Swelling as The First Presentation of Systemic Lupus Erythematosus: A Case Report
}

Abdulrhman Al Abdulqader ${ }^{(1,3)}$,Manal Hasan ${ }^{(2,3)}$

(1) King Faisal University, Alhassa, Saudi Arabia, (2) Imam Abdulrahman Bin Faisal University, Dammam, (3) King

Fahad University Hospital, AL Khobar, Saudi Arabia

Corresponding author: Abdulrhman Al Abdulqader,email: doctorakq@ hotmail.com,mobile:+966555917740

\begin{abstract}
Background: Systemic lupus erythematosus (SLE) is an autoimmune disease that affects multiple systems. Systemic lupus erythematosus is a disease of 1000 faces and can present with ocular manifestations. Early recognition and treatment are essential to prevent morbidities which can reach up to blindness. Ocular involvement occurs in around $30 \%$ of SLE patient.
\end{abstract}

Materials and methods: A case of 40-years-old female complained of an acute periorbital edema with visual involvement concurrent with arthralgia.

Results: Ophthalmology evaluation showed ulcerative keratitis. Laboratory investigation showed leukopenia and anemia. Immunological screening showed high positive Anti-nuclear antibody (ANA), anti-double-stranded DNA and low complements level. Magnetic resonance imaging (MRI) of the brain with contrast showed left optic disc swelling and bilateral periorbital edema. The patient was diagnosed as SLE with ocular manifestations and started on pulse steroid therapy with immunoglobulin intravenous infusion. Her ocular manifestation improved and follow up MRI showed improvement of the Left optic disc swelling.

Conclusion: Optic nerve disease is a rare ocular manifestation of SLE. It is important to recognize it early to avoid serious complication and blindness.

Keywords: Systemic lupus erythematosus, optic disc swelling, ocular manifestations.

\section{INTRODUCTION}

Systemic lupus erythematosus is an autoimmune disease with multisystem involvement. Ocular manifestations can be the first clinical picture of SLE. Keratoconjunctivitis sicca is the most common ocular manifestation ${ }^{(1)}$. Other manifestations include episcleritis,

scleritis, anterior uveitis and exudative retinal detachment. About one percent of patient with SLE will develop optic nerve involvement, which can be due to vasculitis or thrombosis if SLE associated with antiphospholipid antibody syndrome ${ }^{(2)}$. 
Table (1): Timeline including admission, management and follow-up

\begin{tabular}{|c|c|c|}
\hline $\begin{array}{c}\text { Date } \\
\text { April / 2015 } \\
\end{array}$ & \multicolumn{2}{|c|}{$\begin{array}{l}\text { 40-years-old Saudi female presented with a one-month history of bilateral eyelid swelling } \\
\text { which was associated with blurred vision, bilateral eye pain and bilateral knee arthralgia. }\end{array}$} \\
\hline Date & Summary of admission or follow up & Note \\
\hline April / 2015 & $\begin{array}{l}\text { Hospital admission: } \\
\text { Clinical feature: } \\
\text { Bilateral lid edema, chemosis, peripheral ulcerative } \\
\text { keratitis, bilateral optic disc swelling, and inferior } \\
\text { serous retinal detachment } \\
\text { Bilateral knee arthritis } \\
\text { Laboratory tests: } \\
\text { Low WBC and Anemia } \\
\text { Highly positive ANA, anti-dsDNA } \\
\text { Low C3 and C4 }\end{array}$ & $\begin{array}{l}\text { Fulfil } 2015 \text { ACR/SLICC Revised } \\
\text { Criteria for diagnosis of SLE }\end{array}$ \\
\hline April / 2015 & MRI of the brain & $\begin{array}{l}\text { Showed left optic disc swelling and } \\
\text { bilateral periorbital edema }\end{array}$ \\
\hline April / 2015 & SLE diagnosis established & $\begin{array}{l}\text { Started methylprednisolone pulse } \\
\text { therapy and IGIV then discharged with } \\
\text { oral prednisolone and azathioprine. }\end{array}$ \\
\hline May / 2015 & $\begin{array}{l}\text { Outpatient SLE clinic follow up: The bilateral knee } \\
\text { pain and swelling improved. } \\
\text { Ophthalmology clinic follow up : } \\
\text { Healing of peripheral ulcerative keratitis } \\
\text { Improving both lid edema and chemosis } \\
\text { Inferior serous retinal detachment still present } \\
\text { bilaterally with blurred vision. }\end{array}$ & $\begin{array}{l}\text { Increased azathioprine dose to } 100 \mathrm{mg} \\
\text { per oral once daily } \\
\text { Addition of hydroxychloroquine } 400 \\
\text { mg per oral once daily } \\
\text { Started tapering the prednisolone dose } \\
\text { from } 60 \mathrm{mg} \text { every } 5 \text { days by } 5 \mathrm{mg} \text { till } \\
30 \mathrm{mg} \text { once daily. }\end{array}$ \\
\hline June / 2015 & $\begin{array}{l}\text { Outpatient SLE clinic follow up: } \\
\text { Blurred vision improved } \\
\text { Absence of tibiofemoral joint tenderness } \\
\text { WBC and Hemoglobin normalized }\end{array}$ & $\begin{array}{l}\text { Tapered the prednisolone dose from } 35 \\
\text { mg every } 5 \text { days by } 5 \mathrm{mg} \text { till } 10 \mathrm{mg} \\
\text { once daily. }\end{array}$ \\
\hline$\underset{2015}{\text { August / }}$ & $\begin{array}{l}\text { Outpatient SLE clinic follow up: } \\
\text { New complaint of muscle pain and Hair loss which } \\
\text { was most likely side effect of hydroxychloroquine } \\
\text { ESR } 15 \mathrm{~mm} / \mathrm{hr}\end{array}$ & Discontinued hydroxychloroquine. \\
\hline $\begin{array}{l}\text { September / } \\
2015\end{array}$ & $\begin{array}{l}\text { Outpatient SLE clinic follow up: ESR } 25 \mathrm{~mm} / \mathrm{hr} \\
\text { Ophthalmology clinic follow up: Resolving of the } \\
\text { inferior serous retinal detachment bilaterally }\end{array}$ & Arranged for follow up brain MRI \\
\hline $\begin{array}{l}\text { September / } \\
2015\end{array}$ & MRI of the brain & $\begin{array}{l}\text { Normalization of the previously } \\
\text { documented left disc swelling and } \\
\text { periorbital edema }\end{array}$ \\
\hline
\end{tabular}

SLE - Systemic lupus erythematosus, ACR/SLICC - American College of Rheumatology/Systemic Lupus International Collaborating Clinics, WBC - white blood cell, C3 - complement 3, C4 - complement 4, ANA - antinuclear antibody, antidsDNA- anti-double-stranded DNA.

Table (2): The common differences between optic neuritis, non-arteritic ischemic optic neuropathy, and arteritic ischemic optic neuropathy.

\begin{tabular}{|c|c|c|c|}
\hline & Optic neuritis & $\begin{array}{l}\text { Arteritic ischemic } \\
\text { optic neuropathy }\end{array}$ & $\begin{array}{l}\text { Non-arteritic ischemic } \\
\text { optic neuropathy }\end{array}$ \\
\hline Age & $20-50$ years & $>70$ years & $>50$ years \\
\hline
\end{tabular}


https://ejhm.journals.ekb.eg/

\begin{tabular}{|c|c|l|c|}
\hline Pain & \multicolumn{1}{|c|}{$>90 \%$} & $\begin{array}{c}\text { Features of temporal } \\
\text { arteritis }\end{array}$ & Uncommon \\
\hline Unilateral versus bilateral & Commonly Unilateral & Unilateral or bilateral & Commonly unilateral \\
\hline MRI & Optic disc swelling & Iay show enhancement & Usually normal \\
\hline Visual field defect & Central scotoma & Altitudinal defect & Altitudinal defect \\
\hline
\end{tabular}

Table (3): Causes of inflammatory optic neuropathy other than SLE

examination apart from musculoskeletal examination which revealed minimal bilateral knee effusion as well

Ethical considerations: Approval was given by the IRB prior to the as tibiofemoral joint tenderness but no limitation in the range of motion. Ophthalmologic examination showed:

\begin{tabular}{|c|c|}
\hline & Comment \\
\hline Postviral optic neuritis & $\begin{array}{l}\text { - Associated with measles, mumps, chickenpox, influenza, and } \\
\text { Epstein-Barr } \\
\text { - Typically follow the infection by } 2 \text { weeks. } \\
\text { - Visual recovery is usually excellent, even with no treatment. }\end{array}$ \\
\hline Sarcoidosis & $\begin{array}{l}\text { - Optic neuropathy occurs in about } 5 \% \text { of patients } \\
\text { - The optic disc may have a nodular appearance indicate } \\
\text { granulomatous infiltration. }\end{array}$ \\
\hline Systemic autoimmune disease & $\begin{array}{l}\text { - } \quad \text { Sjögren's syndrome } \\
\text { - } \quad \text { Behçet's syndrome } \\
\text { - } \quad \text { Inflammatory bowel disease } \\
\end{array}$ \\
\hline
\end{tabular}

initiation of the study.

\section{CASE PRESENTATION}

\section{Patient information:}

A 40-years-old Saudi female who was known as a case of sickle cell trait and Glucose-6-phosphate dehydrogenase deficiency (G6PD deficiency) presented with a one-month history of bilateral eyelid swelling, which was associated with blurred vision and bilateral eye pain, which increased in severity gradually in the last month.

The patient gave a history of bilateral knee arthralgia which started since 2 weeks prior to admission.

\section{Clinical findings:}

General physical examination revealed a middleaged female with pallor and a normal systemic
Visual acuity in the right eye is 20/60 but in the left eye $20 / 25$. Full range movement bilaterally of the extraocular muscles. Pupils were equal, round, reactive to light and accommodation bilaterally. There was bilateral lid edema, and conjunctiva showed chemosis. Upon corneal examination, the right eye showed peripheral ulcerative keratitis while the left eye was clear. Anterior chambers were quiet bilaterally. Fundus examination showed bilateral optic disc swelling nasally and inferior serous retinal detachment bilaterally.

\section{Diagnostic assessment:}

Laboratory investigations on admission showed as follows (Normal range in brackets): Low white blood cell count 3,000 cells/micrL $(4,000-11,000 / \mathrm{micrL})$, low hemoglobine level $8.4 \mathrm{~g} / \mathrm{dl}(12-15 \mathrm{~g} / \mathrm{dl})$, normal platlets count $204 \times 10^{9} / \mathrm{L}\left(150-450 \times 10^{9} / \mathrm{L}\right)$, high erythrocyte sedimentation rate $120 \mathrm{~mm} / \mathrm{hr}(0-29 \mathrm{~mm} / \mathrm{hr})$. Renal function test and liver function test were normal.

Immunological screening showed (Normal range in brackets): high positive homogenous antinuclear 
antibody titer (ANA) 1:1280, high anti-double-stranded DNA (anti-dsDNA) > 1280, low complement 3 (C3) level $30.6 \mathrm{mg} / \mathrm{dl}(88-206 \mathrm{mg} / \mathrm{dl})$ and low complement 4(C4) level $2 \mathrm{mg} / \mathrm{dl}(13-75 \mathrm{mg} / \mathrm{dL})$. The following immunological screening tests were negative: lupus anticoagulant, anti-cardiolipin antibodies immunoglobulin $\mathrm{M}$ and $\mathrm{G}$, anti-beta2-glycoprotein antibodies immunoglobulin $\mathrm{M}$ and $\mathrm{G}$ and rheumatoid factor (Table 1). On the third day of admission, MRI of the brain carried out, which showed left optic disc swelling and bilateral periorbital edema (Figure1).

Clinical, laboratory and immunological findings all together fulfill 2015 Systemic Lupus International Collaborating Clinics/American College of Rheumatology (ACR/SLICC) Revised Criteria for diagnosis of $\operatorname{SLE}^{(13)}$.

\section{Therapeutic intervention:}

The patient was started on pulse steroid therapy with methylprednisolone one gram intravenous once daily for 3 days and intravenous immunoglobulin infusion (IGIV) a total of $2 \mathrm{~g} / \mathrm{kg}$ over 2 days.

The patient was discharged home on the eighth day of admission with prednisolone $60 \mathrm{mg}$ per oral once daily in addition to azathioprine $50 \mathrm{mg}$ per oral once daily. Then, outpatient SLE and ophthalmology clinics follow up.

\section{Follow-up and outcomes:}

Upon outpatient SLE clinic follow up after discharge, the blurring of vision was improved. Chemosis and lid edema disappeared, visual acuity improved. On musculoskeletal examination, there was much improvement in the form of absence of the previously documented knee effusion and tibiofemoral joint tenderness (Table 1).

Follow up of orbital MRI with contrast, which was carried out 5 months after the first MRI, showed normalization of the previously documented left disc swelling and periorbital edema (Figure 2).

Figure (1): Orbital MRI with contrast (T2/flair) showing left optic disc swelling (yellow arrow), which can be identified by haziness and loss of the optic disc margins compared to the normal clear convex right optic disc (green arrow). Bilateral periorbital edema (blue arrows)

Figure (2): Orbital MRI with contrast showing normalization of the left optic disc (yellow arrow) and absence of bilateral periorbital edema (blue arrows) after therapy.

\section{DISCUSSION}

Despite the $30 \%$ prevalence of ocular manifestation in $\mathrm{SLE}^{(3)}$, only $1 \%$ will have optic nerve involvement ${ }^{(1)}$. Other SLE ocular manifestation can be classified according to their location into extraocular disease, anterior segment disease and posterior segment disease ${ }^{(4)}$. Extraocular disease includes eyelid disease, which presents with discoid lupus-type rash over the eyelids ${ }^{(1)}$, dry eye syndrome usually accompanied by Sjogren's syndrome and periorbital edema. Anterior segment disease includes corneal erosions present with a painful, watery eye, peripheral ulcerative keratitis, which is rare and it indicates active disease, episcleritis, scleritis and anterior uveitis. Posterior segment disease includes SLE retinopathy, retinal vascular occlusion, choroidopathy, optic neuritis, and ischemic optic neuropathy. As SLE is a multifactorial autoimmune disease, the exact pathogenesis still unknown. The possible pathogenesis of optic nerve involvement in SLE is due to abnormal activation of autoantibodies and complements which lead to vasculitis or thrombosis to the arterioles supplying the optic nerve which end in

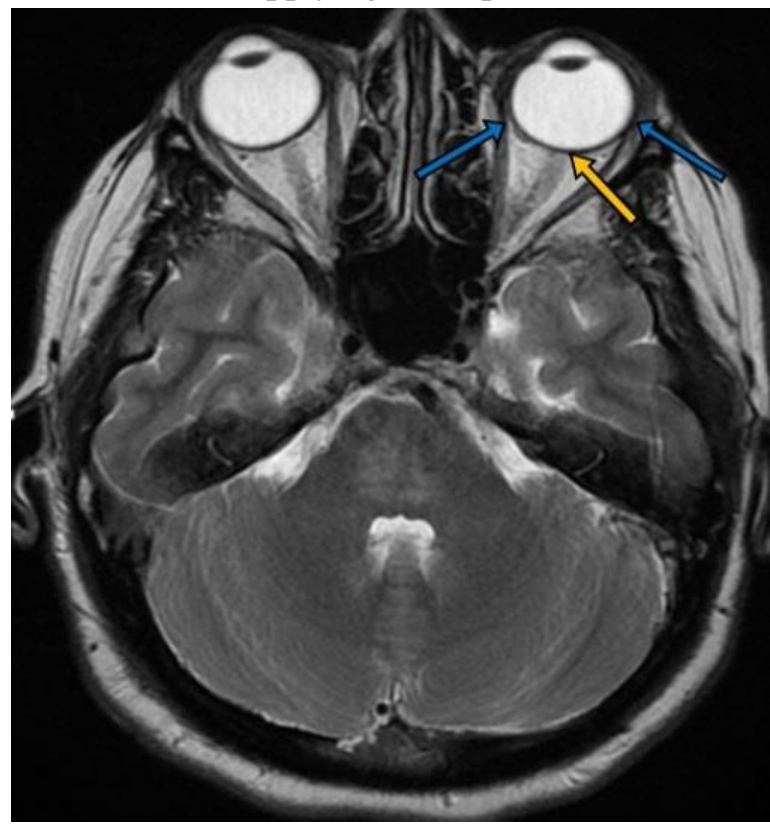

inflammatory optic neuropathy.

Optic nerve disease is a rare manifestation of SLE

(5). It consists of 2 entity, optic neuritis, and ischemic optic neuropathy. Optic neuritis is a clinical-based diagnosis and usually present acutely within hours to days and affects single eye with sparing of the other and could be associated with pain especially with eye 
movement. If there is no other SLE features, it is difficult to differentiate optic neuritis secondary to SLE from optic neuritis of demyelinating diseases like multiple sclerosis ${ }^{(1)}$. Ischemic optic neuropathy can be divided into non-arteritic ischemic optic neuropathy and arteritic ischemic optic neuropathy (Table2). Many causes other than SLE can cause inflammatory optic neuropathy such as post-viral optic neuritis, sarcoidosis and systemic autoimmune diseases (Table 3). Treatment of inflammatory optic neuropathy secondary to SLE is with pulse steroid therapy followed by taper down. Intravenous immunoglobulins or plasma exchange can be added to the pulse steroid therapy ${ }^{(1)}$. Other studies have shown improvement with other agents such as cyclosporine, cyclophosphamide, and azathioprine ${ }^{(4,6)}$.

Ischemic optic neuropathy is less likely a cause of this case, as it is suggested by the following: young age of the patient, absence of risk factors for vascular ischemia such as diabetes mellitus or hypertension, no features suggestive of temporal arteritis, presence of MRI change which is usually absent in ischemic optic neuropathy, and the dramatic change and improvement in visual field after the steroid pulse therapy and IGIV with azathioprine. So with MRI showing left optic disc swelling, serology and clinical evidence of SLE, with the dramatic response to steroid and immunosuppressive agents and improvement of the optic disc swelling in a follow-up MRI. All those collectively make the diagnosis of optic neuritis secondary to SLE is the most likely diagnosis in our case.

\section{CONCLUSION}

Optic nerve disease is a rare ocular manifestation of SLE. It is important to recognize it early to avoid serious complication and blindness.

\section{REFERENCES}

1. Sivaraj R R, Durrani O M, Denniston A K, Murray P I, Gordon C (2007): Ocular manifestations of systemic lupus erythematosus. Rheumatology, 46 (12): 1757-1762.

2. Iraj S (2015): ACR/SLICC Revised Criteria for Diagnosis of Systemic Lupus Erythematosus. Autoimmune Dis Ther Approaches Open Access, 2: 114

3. Palejwala N V, Walia H S, Yeh S (2012): Ocular manifestations of systemic lupus erythematosus: a review of the literature. www.ncbi.nlm.nih.gov > pubmed

4. Boonsopon S, Maghsoudlou A, Foster CS (2015): Ocular Manifestations in Systemic Lupus Erythematosus. Rheumatology (Sunnyvale), 5: 150.

5. Frigui M, Frikha F, Sellemi D, Chouayakh F, Feki J, Bahloul Z (2011): Optic neuropathy as a presenting feature of systemic lupus erythematosus: two case reports and literature review. Lupus, 20 (11): 1214-1218.

6. Rosenbaum J T, Simpson J, Neuwelt C M (1997): Successful treatment of optic neuropathy in association with systemic lupus erythematosus using intravenous cyclophosphamide. British Journal of Ophthalmology, 81 (2): 130. 